JOURNAL OF HEALTH SCIENCE AND PREVENTION

http://jurnalfpk.uinsby.ac.id/index.php/jhsp

ISSN 2549-919X (e)

\title{
Career Path to Nurse Job Satisfaction In The Hospital
}

\author{
Azwar1, Nur Hidayah'2, Andi Adriana Amal'2, Syamsiah Rauf ${ }^{2}$ \\ ${ }^{1}$ Nursing Student, Faculty of Medicine and Health Sciene UIN Alauddin Makassar \\ ${ }^{2}$ Nursing Management Department, Faculty of Medicine and Health Sciene UIN Alauddin Makassar \\ Corespondence e-mail: azwarmuhtar@gmail.com \\ DOI: http:// doi.org/10.29080/jhsp.v3i3S.298
}

\begin{tabular}{l}
\hline Keywords \\
\hline Career paths; \\
Nurse Career Paths; \\
Nurse satisfaction
\end{tabular}

\begin{abstract}
The high number of nurses who work can illustrate that nurses have an important role in improving health status so that strategic steps are needed in managing nursing staff in a better direction. As for the impact caused by uncontrolled nursing staff is dissatisfaction with nurses nurses so that the decline in nurse performance in providing nursing care to patients so that nurse satisfaction is an indicator that must be considered by all parties concerned. The solution to this problem is the issuance of the Government Regulation of the Republic of Indonesia through the ministry of health which has issued a policy regarding nurses' career paths as an embodiment in improving the quality of nursing staff and is expected to be able to increase nursing staff satisfaction. The writing of this article aims to see how the career path influences the satisfaction of nurses in the hospital. Literature and research review was carried out using several databases: 12 articles from Google Scholar and Pubmed with key words in nurse careers, performance, nurses and nurse satisfaction with career paths. From the results of a review of several journals included in the inclusion criteria, it was found that nurses' career paths had good effectiveness towards increasing nurse satisfaction, this can be seen by the existence of a continuous education system and work rewards that are owned by the career level system.
\end{abstract}

\section{Introduction}

Health workers are the most important element in efforts to improve public health both individuals, families and communities. One of the efforts to improve health status is to manage health workers optimally so that they are able to carry out their respective duties and authorities in order to realize a quality health degree. The most important health workers are medical personnel, nursing, midwifery, pharmacy, public health and other health workers who collaborate and work together Nursing staff as health workers with the highest presentation in Indonesia with a presentation of $49 \%$. (1).compared to other health workers make nursing staff have the greatest potential in providing excellent service in order to improve health status in Indonesia(2). However, when nursing staff fails to be managed and empowered it will have a large impact on the wheel of circulation of the world of health, such as the occurrence of dissatisfaction with nurses whose ends will have an impact on decreasing the quality of providing nursing care to patients. The cause of nurses' dissatisfaction is the absence of recognition and incentives received by nurses and the absence of strong motivation from nurses to carry out comprehensive nursing care.

Seeing the increasing need for nursing staff, the government through the health ministry provided the latest breakthrough by issuing a policy in the form of Republic of Indonesia Minister of Health Regulation Number 40 of 2017 concerning Clinical Nurse Career Development. Nurse career path models have been widely applied in various countries such as the Blakemore Career pathways model that is applied to countries in the Continent of Europe, Australia and America while the Chiang-Hanisko Career Pathways model is widely applied in countries in the Asian and African Continent(3).

Career paths have been applied in Indonesia since 2013 with the implementation of nurse career paths, but not many have applied because there are no rules governing career paths. But in 2017 the nurse career path has been set directly by the government so that the career path is feasible to apply. Some research results indicate that career paths can have a good impact on nurses where effective career levels in increasing satisfaction from within nurses (4), then reinforced by the research conducted and the results obtained that career paths have a relationship to nurse satisfaction who work in health care facilities (5). On the basis of the above, the author has the assumption that a literature review is needed regarding the 
effectiveness of career paths in overcoming dissatisfaction of nurses working in hospitals

\section{Method}

This literature search uses searching methods from textbooks, ebooks, and journals or original research that relates to satisfaction and career paths of nurses both from within and outside the country from search database sources on Google Scolar and Pubmed with keyword career path levels for nurses Nurse satisfaction.

The electronic data base, namely Google Scholar and Pubmed, is used as the word kuci "The career path for nurses, nurse satisfaction". The combination of keywords used aims to provide broad coverage on the results of the literature search, not focusing on other specific factors (such as nurses, nurse satisfaction, etc.) because the purpose of this literature review is to provide a general review of the topics discussed. After identifying relevant articles, longitudinal studies were carried out and literature selection was appropriate for use in the review. The process carried out was carried out repeatedly by the second and third researchers. There are inclusion and exclusion criteria in the literature used. The inclusion criteria used are: (1) Journals published in 2008-2018, (2) Journals in English and Indonesian (while the exclusion criteria used are: (1) Journals published outside of 2008-2018 (2) The study is not about nurse career paths and career paths of nurse job satisfaction.

The identification of the literature at the beginning of the search gets 25 articles, but 5 articles are the same article. Furthermore, the remaining 12 articles were re-identified based on established inclusion and exclusion criteria. The final results of the identification were obtained 12 articles that were in accordance with the established inclusion criteria. Then the articles included in the inclusion criteria will be reviewed to see how many career paths influence the satisfaction of nurses working in hospitals.

\section{Result and Discussion}

Nurses in doing work are required to always prioritize a sense of professionalism so that with these responsibilities nurses are able to get satisfaction in work. Job satisfaction can describe the level of how someone likes his job. So that job satisfaction is very important for nurses who work in hospitals.

The factors that influence nurse job satisfaction are salary, promotion satisfaction, supervision satisfaction, coworker satisfaction, and job satisfaction. Then these factors are all included in the nurse career system indicator.

Some research results (6-10), found that career paths have a relationship related to nurse satisfaction. This means that nurses will always experience satisfaction with performance with the recognition or development provided by the career path of nurses in hospitals as well as vice versa if nurses in hospitals are not getting recognition or development either from the career path system or from other hospital management programs so nurses tend to experience work boredom.

One of the factors that influence the high performance results of nursing staff is the reason why career paths must be implemented well because the existence of this system will reduce ambitious employee turnover who will be frustrated and look for other jobs due to lack of progress in work (11) or in other words nurses are not satisfied with the position they have achieved during their work so that this can make nurses leave the workplace.

In supporting the implementation of a more optimal career path there is a need for support from various parties such as hospital leaders, other health personnel as well as nurses themselves so that hospital management must be smart to see and formulate what is needed by nursing staff in line with research results (12) that there is a relationship between superiors' support, and peers on the optimal application of career paths in hospitals, then the results of other studies show that nurses quit workers in Switzerland due to lack of appreciation management in involving nurses in decision making. So that in the application of career paths in the hospital can be to involve all elements of existing resources.

\section{Conclusions}

Career paths have a relationship in increasing the satisfaction of nurses working in hospitals so it is expected that there is support from various parties in implementing career paths in hospitals because career paths have a variety of appropriate indicators in overcoming nurse boredom.

\section{References}

1. Kementerian Kesehatan RI. Pusat Data dan Informasi Kementerian Kesehatan RI. 2017.

2. Hariyati TS. Perencanaan Pengembangan Dan Utilisasi Tenaga Keperawatan. Jakarta: PT Raja Grafindo Persada; 2014. 
3. Purwandari A. Model-Model Jenjang Karir Perawat di Dunia.

4. Ratanto. Pengembangan Karir = Faktor Paling Mempengaruhi Kinerja Perawat Pelaksana. Jurnal Husada Mahakam. 2013;3(5):200-62.

5. Gunawan A. Pengaruh Kompensasi Dan Pengembangan Karir Terhadapkepuasan Kerja Perawat Yang Dimediasi Oleh Motivasi Kerja Pada Rumah Sakit Bina Kasih Pekanbaru. JOM Fekon [Internet]. 2017 [cited 2019 Dec 6];4(1). Available from: https://media.neliti.com/media/publications/116530-IDpengaruh-kompensasi-dan-pengembangan-kar.pdf

6. Sitinjak L. Pengaruh penerapan sistem jenjang karir terhadap kepuasan perawat di RS PGI "Cikini" Jakarta. [Jakarta]: Fakultas Ilmu Keperawatan UI; 2008.

7. Suroso J. Penataan Sistem Jenjang Karir Berdasar Kompetensi Untuk Meningkatkan Kepuasan Kerja Dan Kinerja Perawat Di Rumah Sakit. 2011;6:9.

8. Hardjanti IW, Faramita NI, Hartojo H. Pengembangan Jenjang Karir sebagai Strategi Mengelola Ketidakpuasan Kerja Perawat di Rumah Sakit. Jurnal Kedokteran Brawijaya. 2016 Aug 30;29(3):285-90.

9. Suhartono JF, Sawitri HSR. Pengaruh reward, insentif, pembagian tugas dan pengembangan karier pada kepuasan kerja perawat di rumah sakit ortopedi Prof. Dr. R. Soeharso Surakarta. Benefit: Jurnal Manajemen dan Bisnis. 2017 Jun 15;2(1):28-44-44.

10. Kolibu FK, Hariyanto T, Pusparahaju A. Pengembangan Model Jenjang Karir Perawat Klinis di Unit Rawat Inap Rumah Sakit. Jurnal Kedokteran Brawijaya. 2014 Aug 3;28(1):59-64.

11. Marquis BL, Huston CJ. Kepemimpinan dan Manajemen Keperawatan. Jakarta: EGC; 2013.

12. Pasang MT, Kadar K, Natzir R. Nurses' Perceptions and Expectations on The Implementation of Career Ladder in Public Hospitals in Makassar. Indonesian Contemporary Nursing Journal. 2017 Aug 30;2(1):307. 